\title{
Karakter Kejujuran dalam Gereja Masa Kini
}

\section{The Character of Honesty in the Church Today}

\author{
Marsi Bombongan Rantesalu ${ }^{1{ }^{*}}$ \\ 1) IAKN Kupang \\ *Penulis Korespondensi: marsibombongan@gmail.com
}

Received: 0706 2020/Revised: 1106 2020/ Accepted: 12062020

\begin{abstract}
Abstrak
Masalah rapuhnya karakter kejujuran dewasa ini tidak hanya menjadi momok di dunia sekuler, tetapi juga terjadi dalam lingkungan Gereja. Gereja yang seharusnya menjadi tempat membentuk dan menumbuhkan nilai karakter Kristiani, salah satunya karakter kejujuran, tidak pelak dinodai oleh tindakan oknum-oknum dalam gereja itu sendiri, baik oleh jemaat maupun pemimpin jemaat. Masalah seperti pengelolaan keuangan yang tidak transparan, ketidakjujuran dalam hal memberi persembahan adalah contoh kecilnya. Penelitian ini bertujuan untuk mencari beberapa hal yang menjadi permasalah berkaitan dengan praktik ketidakjujuran dalam jemaat. Metode yang digunakan Pada penelitian ini adalah metode deskriptif kualitatif dengan studi kepustakaan. Dari hasil penelitian ini disimpulkan bahwa kejujuran dalam jemaat masa kini perlu dimiliki setiap orang sebagai implementasi karakter yang Alkitabiah serta merupakan bentuk tanggung jawab dalam persekutuan.
\end{abstract}

Kata-kata Kunci: Gereja, Jemaat, Karakter, Kejujuran, Nilai.

\begin{abstract}
The problem of the fragility of the character of honesty today is not only a scourge in the secular world, but also occurs in the Church environment. The church which is supposed to be a place to form and foster Christian character values, one of which is the character of honesty, is undoubtedly tarnished by the actions of individuals in the church itself, both by the congregation and the church leaders. Issues such as financial management that are not transparent, dishonesty in terms of offering offerings are a small example. This study aims to look for some things that become problems relating to the practice of dishonesty in the congregation. The method used in this research is descriptive qualitative method with literature study. From the results of this study it was concluded that honesty in today's church needs to be had by everyone as an implementation of biblical character and a form of responsibility in fellowship.
\end{abstract}

Keywords: Character, Church, Congregation, Honesty, Values. 


\section{PENDAHULUAN}

Dalam sejara umat manusia terlihat jelas melalui ajaran Alkitab bahwa benih ketidakjujuran itu sudah ada sejak manusia jatuh ke dalam dosa. Ketika Adam dan hawa melanggar perintah Allah untuk tidak memakan buah yang diperintahkan, manusia itu memilih jalan untuk bersembunyi. Tidak ada keinginan dari mereka untuk datang kepada Allah, justru sebaliknya Allah yang berinisiatif mencari mereka. Ketidakjujuran menjadi bagian dalam diri manusia saat itu yang kemudian terus diwariskan kepada keturunannya hingga kini.

Dewasa ini sudah sangat sering media menyuguhkan kepada pembaca atau penontonnya berita-berita tentang kejahatan yang terjadi akibat dari kebiadaban manusia yang bersumber dari kepribadian yang tidak jujur. Kecenderungan mementingkan diri sendiri kemudian menghilangkan rasa empati kepada orang lain. Sesuatu yang seharusnya diikmati bersama di curi demi memuaskan nafsu pribadi tertentu. Sudah menjadi konsumsi umum tentang koruptor yang melakukan perbuatannyai secara terstruktur dan dalam kapasitas yang besar, sehingga membuat negara kita masuk dalam daftar negara terkoruptor pada peringkat sepuluh besar dunia (Djadi, 2005, p. 41).

Data di atas hanya merupakan bagian kecil perbutan-perbuatan tidak jujur yang terjadi dan yang terlihat. Pada dasarnya perbuatan-perbuatan tersebut meenggambarkan bahwa nilai-nilai kejujuran itu sudah mulai punah (Putri \& Dewantara, 2018, p. 1), Sehingga tidak salah jika dikatakan kejujuran merupakan hal yang langkah dan mahal. Hilangnya nilai kejujuran itu kemudian menimbulkan ketidakpercayaan antara satu pribadi dengan pribadi yang lain. Terjadi krisis kepercayaan yang mengakibatkan munculnya jarak sosial di tengah masyarakat.

Melihat gentingnya persoalan kejujuran ini maka sangat penting untung meningkatkan pendidikan karakter sejak dini. Pendidikan karakter dalam sistem pendidikan di Indonesia adalah salah satu bagian yang harus dimaksimalkan (Wijaya \& Helaluddin, 2018, p. 1). Menurut Amin salah satu inti dari pendidikan karakter adalah penanaman nilai kejujuran (Amin, 2017, p. 106). Hal lain diungkapkan oleh umar yang mengatakan manusia akan bertindak sesuai dengan nilai yang diyakininya. Semakin kuat nilai yang dipilih semakin kuat pula pengaruh nilai tersebut terhadap kehidupannya. Salah satunya adalah nilai kejujuran (Mansyur, 2018, p. 4). Menurut Mardikarini dan Suwarjo karakter dapat berkembang secara maksimal jika dalam pembelajaran juga dikembangkan nilai-nilai karakter. Nilai karakter yang dimaksud adalah nilai religiusitas, kejujuran, kedisiplinan, tanggung jawab, kesantunan, kepedulian, dan kepercayaan diri (Mardikarini \& Suwarjo, 2016, p. 262). Menurut Setiawan pendidikan karakter yang unggul bagi seseorang dapat dilakukan melalui pembinan kerohanian (Setiawan, 2019, p. 153). 
Dari beberapa pendapat ini dapat disimpulkan bahwa karakter kejujuran itu sebenarnya bisa diwujudkan tentunya dengan peran yang signifikan dari berbagai pihak seperti keluarga, sekolah (Guru) dan tentunya dalam komunitas gereja. Gereja bertanggung jawab mengatasi praktik ketidakjujuran dengan memaksimalkan seluruh potensi yang dimilikinya(Simangunsong, 2018, p. 207).

Kejujuran ini bukan saja bermasalah pada dunia sekuler seperti yang telah diungkapkan sebelumnya, tetapi juga terjadi dalam lingkungan Gereja. Gereja yang seharusnya menjadi tempat membentuk dan menumbuhkan nilai karakter Kristiani, salah satunya karakter kejujuran, tidak pelak dinodai oleh tindakan oknum-oknum dalam gereja itu sendiri, baik oleh jemaat maupun pemimpin jemaat. Masalah seperti pengelolaan keuangan yang tidak transparan, ketidakjujuran dalam hal memberi persembahan, ketidakjujuran dalam pengakuan kesalahan bahkan ketidakjujuran dalam pelayanan mimbar serta banyak kasus yang lain merupakan hal yang sering dijumpai dalam gereja.

Penelitian ini akan menyoroti beberapa hal yang berkaitan dengan praktik kejujuran dalam jemaat. Peneliti-peneliti sebelumnya telah mengkaji beberapa hal mengenai kasus-kasus dalam jemaat berkaitan dengan hal kejujuran ini. Penelitian Komang Gede Suriani Suan Dewi dan kawan-kawan pernah membahas tentang akuntabilitas keuangan dalam gereja (Dewi et al., 2015, p. 2). Sedangkan penelitian Franchisca Sukmawati mengatakan Akuntabilitas keuangan secara vertikal kepada Tuhan dapat dilakukan dengan mengelola kas gereja dengan jujur dan penuh tanggung jawab. Sedangkan bentuk akuntabilitas keuangan secara horisontal dapat dilakukan dengan mempublikasikan laporan keuangan. Publikasi pelaporan keuangan yang dilakukan oleh harus dilakukan untuk menjaga amanah dalam mengelola keuangan gereja, (Sukmawati et al., 2020).

Pembahasan dalam Penelitian ini berbeda dengan hasil penelitian-penelitian sebelumnya yang berfokus kepada kejujuran dalam pengelolaan keuangan gereja. Penelitian ini lebih fokus pada pembahasan beberapa bagian yang berkaitan dengan masalah nilai-nilai kejujuran dalam bergereja atau berjemaat.

\section{TEORI}

Menurut Nuhamara Karakter adalah kebajikan yang dimiliki seseorang yang bisa saja bersumber dari keyakinan iman seseorang (Nuhamara, 2018, p. 113). Kejujuran adalah Komponen rohani yang memantulkan berbagai sikap terpuji (Inten, 2017, p. 36). Karakter merupakan sesuatu yang ada pada diri seseorang yang berkaitan perilaku yang positif. Oleh karena itu karakter seseorang dapat terlihat dalam kehidupannya sehari-hari, sedangkan kejujuran yang berasal dari kata dasar "jujur" dapat dimaknai dengan kesesuain ucapan dengan kenyataan. Dalam pengertian yang lebih umum jujur berarti sesuainya lahir dan batin (Murdiono, 2016, p. 169). Dari beberapa pendapat tersebut maka dapat disimpulkan bahwa Karakter Kejujuran 
merupakan suatu kesatuan antara ucapan dan tindakan seseorang yang terlihat pada perilakunya yang positif dan hal itu bersumber dari keyakinan iman orang tersebut.

Menurut Jhon White kejujuran merupakan mandat dari Alkitab, karena Alkitab menuntut standar kejujuran yang tinggi. Kejujuran yang dijelaskan oleh Alkitab bukan hanya sekedar tidak berbohong namun Kejujuran melibatkan keseluruhan cara hidup benar dan juga pola pemikiran yang patut sehingga menghasilkan cara hidup seseorang yang terpuji. Bentuk-bentuk karakter kejujuran menurut White adalah kejujuran dalam bisnis, Kejujuran dalam rumah tangga, Kejujuran para mahasiswa, Kejujuran dalam gereja dan kejujuran terhadap diri sendiri. Berkaitan dengan kejujuran dalam gereja dia memaparkan bagian-bagian dimana setiap warga gereja harus jujur antara lain: kejujuran dalam hubungan-hubungan, Kejujuran dalam perselisihan, kejujuran dalam kepemimpinan, serta Kejujuran dan efektifitas gereja (White, 2012, pp. 124-150).

Berangkat dari teori white tersebut maka dalam penelitian ini penulis berusaha melihat nilai-nilai karakter kejujuran yang penting diterapkan dalam kehidupan bergereja dan berjemaat pada masa kini.

\section{METODE}

Penelitian kualitatif bersifat deskriptif artinya data yang terkumpul berbentuk kata-kata atau gambar, sehingga tidak menekankan pada angka, (Sugiyono, 2015, p. 16). Jenis penelitian yang digunakan dalam penelitian ini adalah deskriptif kualitatif. Sesuai dengan obyek kajian penelitian ini maka alur yang ditempuh peneliti untuk mendapatkan data yaitu, pertama, dengan mencatat semua temuan mengenai nilai karakter kejujuran yang didapatkan dalam Alkitab serta literatur-literatur dan penemuan terbaru dalam jurnal. Setelah mencatat, langkah kedua, yang dilakukan adalah memadukan temuan dengan temuan-temuan peneliti mengenai karakter kejujuran itu dalam jemaat masa kini. Ketiga, menganalisis temuan dari berbagai bacaan berkaitan dan keempat adalah mendialogkan hasil bacaan dengan temuan mengenai nilai kejujuran dalam gereja untuk menghadirkan temuan baru.

\section{HASIL DAN PEMBAHASAN}

Pada bagian ini penulis akan menyoroti beberapa hal yang berkaitan dengan nilai-nilai karakter kejujuran dalam gereja atau jemaat. hasil penelitian ini merupakan hasil dialog antara sumber alkitab dan sumber kepustakaan dengan temuan dalam gereja atau jemaat. Adapun nilai-nilai tersebut dapat dilihat di dalam pembahasanpembahasan berikut.

\section{Kejujuran dalam Komunikasi}

Liuhua Ying dan kawan-kawan dalam kajiannya mengatakan bahwa Komunikasi adalah kunci untuk membangun dan memperkuat hubungan dan keintiman 
seseorang dan yang lain. Komunikasi yang kurang terbuka menunjukkan peningkatan konflik dan berkurangnya pengakuan atau kejujuran (Ying et al., 2015, p. 2).

Gereja sebagai perkumpulan orang-orang percaya yang berasal dari berbagai latar belakang yang berbeda sangat membutuhkan cara berkomunikasi yang tepat. Kesuksesan mencapai tujuan dalam suatu organisasi (termasuk di dalamnya organisasi gereja) pada dasarnya ditentukan oleh kemampuan dan keterampilan komunikasi pemimpin beserta oknum-oknum yang terlibat di dalamnya (Setyono, 2013, p. 191).

Dalam sebuah persekutuan gereja ada banyak faktor yang melatar belakangi sehingga muncul ketidakjujuran dalam hal komunikasi. Pada pembahasan ini penulis tidak konsen membahas faktor-faktor tersebut. Tetapi salah satufaktor tersebut karena "Ketidakjujuran" dalam komunikasi dalam gereja dianggap sebagai salah satu cara untuk menjaga perasaan dan menjaga hubungan satu dengan yang lain. Kejujuran terkadang dianggap dapat menimbulkan perselisihan dalam jemaat, sehingga orang lebih mengambil keputusan tidak jujur dengan alasan demi kepentingan yang lebih besar. Tentunya pendapat tersebut salah karena Alkitab sendiri mengajarkan untuk berperilaku jujur (Ef.4:12).

Kejujuran bukanlah sebuah hal yang kejam atau sebuah hal yang kasar. Persekutuan yang dilandasi dengan kejujuran dalam komunikasi akan menghasilkan sebuah gereja yang matang dan semakin dewasa. Yang terpeniting disini adalah cara mengembangkan komunikasi yang jujur dalam berkomunikasi. Dalam hal ini Jerry White memberikan saran-saran dalam berkomunikasi secara jujur dalam berjemaat dan bergereja (White, 2012, p. 124), antara lain:

Pertama, Mintalah Allah agar memberikan motivasi yang benar kepada anda. Motivasi komunikasi yang harus dibentuk dalam jemaat adalah untuk mengajar dan membangun orang-orang lain daripada menarik perhatian diri sendiri. Dalam Filipi 2:4. Rasul Paulus berkata "Dan janganlah tiap-tiap orang hanya mementingkan dirinya sendiri tetapi kepentingan orang lain juga." Motivasi yang benar akan membuat kejujuran dalam berkomunikasi dapat diterima oleh pihak lain.

Kedua, Dengarkanlah orang-orang lain. Kebiasaan orang adalah ingi untuk diindahkan atau didengarkan. Kemampuan mendengarkan akan membuat hubungan dapat bertumbuh. Komunikasi bukan berarti banyak berbicara tetapi juga mampu menelaah setiap inti dari pembicaraan dengan mendengar.

Ketiga, Hindarkan canda yang berlebihan serta kata-kata yang menyelah dan menyinggung perasaan orang. Canda atau humor bukanlah hal yang salah, tetapi hal tersebut bisa berakibat fatal jika tidak memperhatikan situasi dan konteks penggunaannya. Ada orang yang suka humor tetapi ada yang lebih serius. Candaan dalam taraf-taraf tertentu dapat diterima tetapi jika berlebihan maka dapat menimbulkan perselisihan.

Keempat, Belajarlah caranya untuk mengajukan pertanyaan-pertanyaan. Dalam menjalin komunikasi dengan orang lain, perlu untuk mempelajari keadaan-keadaan teman berkomunikasi. Pengetahuan akan konteks lawan bicara akan membuat 
seseorang dapat memilih pertanyaan-pertanyaan yang tepat yang bisa dilontarkan. Pertanyaan yang tepat akan direspon dengan jawaban yang baik tetapi jika sebaliknya justru akan menimbulkan ketersinggungan.

Kelima, Nyatakan pandangan-pandangan dengan cara yang jujur tetapi tidak mengancam. Selanjutnya yang harus dilakukan adalah menyampaikan pendapatpendapat dengan cara yang tepat, jujur tetapi tidak mengancam atau tidak memaksakan. Kejujuran dalam menyampaikan pendapat tidak boleh bertujuan menyinggung perasaan orang lain.

Keenam, Ketidaksetujuan Tidak boleh memutus komunikasi. Dalam sebuah persekutuan perbedaan pendapat merupakan sesuatu yang biasa. Perbedaan pendapat pada suatu topik tidak boleh dibawa pada topik-topik yang lain. Hal ini sangat erat kaitannya dengan manajemen emosi. Kemampuan menahan diri dapat membuat komunikasi tetap berjalan baik.

Dari berbagai uraian di atas dapat disimpulkan bahwa Komunikasi dalam kehidupan berjemaat atau bergereja itu penting, tidak kalah pentingnya dengan kejujuran dalam berkomunikasi. Kadangkala begitu susah untuk jujur kepada orang lain demi menjaga perasaan tetapi hal itu harus terus dilakukan demi terciptanya persekutuan yang semakin dewasa di dalam Tuhan. Berkomunikasi dengan jujur menggunakan cara yang tepat akan mendapatkan respon yang baik pula.

\section{Kejujuran dalam Perselisihan (Konflik)}

Perselisihan atau konflik merupakan suatu yang sering terjadi dan dialami oleh setiap warga gereja. Mengenai tema perubahan dan konflik di gereja pengembangan, area dapat dibatasi untuk konflik sosial, berbeda dengan konflik batin dan eksistensial batin. Karakteristik konflik sosial adalah bahwa (a) dalam a struktur sosial, dua kecenderungan tindakan yang berlawanan terjadi, dan (b) ini dialami sebagai cara alternatif untuk mencapai tujuan. Sangat mudah untuk menunjukkan bagaimana konflik dalam perkembangan gereja dapat muncul perubahan. Perubahan dalam masyarakat dan gereja mengarah pada pertanyaan apakah sebuah strategi sebelumnya masih memadai untuk situasi baru. Sebagai contoh, kebebasan yang baru diperoleh tidak menghasilkan pengembalian massal ke gereja-gereja. Adalah ini alasan untuk resah atau tidak? Haruskah gereja berkonsentrasi pada pelestarian identitas mereka, atau mereka harus membuka diri untuk mendapatkan resonansi baru dan relevansi? Apakah gereja berusaha mempertahankan situasi yang tidak mungkin terjadi terawat? Apakah gereja menggunakan energinya hanya untuk mencegah perubahan atau juga untuk membentuk dan membentuk perubahan? Semua pertanyaan ini penting untuk diperhatikan atas reaksi atas konflik dalam Gereja (Zimmermann, 2009, p. 54). Dalam perjanjian baru kasus konflik yang kemudian mengasilkan perluasan dan pertumbuhan jemaat seperti yang terjadi antara Paulus dan barnabas. Saluchu menjelaskan konflik yang terjadi antara Paulus dan Barnabas tidak melahirkan suatu permusuhan, persaingan dan saling serang seperti yang umum ditemui di dalam konflik gereja. Perpisahan Paulus dan Barnabas 
merupakan keputusan yang strategis dengan tujuan perluasan penyebaran Injil Kristus (Zaluchu, 2018, p. 108).

Konflik atau perselisihan dalam gereja sering ditimbulkan oleh banyak waktor. Frans rumbi menjelaskan tentang penyebab terjadinya konflik dalam gereja antara lain dipicu ketidakpuasan antara anggota jemaat dan sering konflik itu muncul akibat pengaruh dari luar. Faktor-faktor dari dalam biasanya karena manajemen gerejawi, program kerja, keuangan dan kebijakan-kebijakan dalam gereja. Faktor dari luar seperti dinamika sosial ideologi, politik, ekonomi, budaya maupun agama dalam masyarakat. Yang fatal adalah konflik yang sengaja dibuat oleh pihak tertentu dalam gereja setempat demi ambisi pribadinya (Rumbi, 2019, p. 10).

Dari paparan tersebut menjelaskan bahwa konflik dalam gereja adalah sesuatu yang nyata dan tidak bisa dihindari. Agar konflik tersebut tidak membesar dan menjadi ancaman bagi jemaat maka perlu pengelolaan konflik secara jujur dan tepat. Resolusi konflik yang tepat justru akan merangsang Pertumbuhan suatu jemaat,(Rumbi, 2019). Menyelesaikan konflik secara jujur dalam jemaat haaruslah melibatkan komponen-kompenen dalam jemaat khususnya pihak yang bertikai. Jhon White menjelaskan beberapa beberapa cara untuk menyelesaikan konflik dengan kejujuran, antara lain: 1) secepat mungkin mengakui bahwa ada perselisihan yang terjadi, sering jemaat yang berselisih tidak memberitahukan akan perselisihan yang terjadi. Kejujuran mengakui adanya perselisihan akan menolong untuk penyelesaian masalah sebelum menjadi lebih besar. 2) ceritakan persoalan kepada orang yang netral, dalam hal ini adalah orang yang dianggap mampu berperan dalam menyelesaikan masalah yang ada. 3) sampaikan perselisihan itu secepat mungkin dalam suatu pembicaraan sifatnya terbuka. 4) bersedia mengakui kesalahan. Kesediaan untuk merendahkan hati dan mengesampingkan ego akan sangat membantu dalam penyelesaian suatu perselisihan. 5) ungkapkan semua pikiran, gagasan dan apa yang dirasakan secara jujur, tidak kasar serta tidak merendahkan orang lain. 6) memulihkan hubungan. Jika terjadi sebuah perselisihan maka yang harus menjadi tujuan pertama adalah memulihkan hubungan. Kejujuran adalah dasar yang kuat dalam memlihara hubungan-hubungan dalam jemaat, (White, 2012, pp. 139-140).

Dari penjelasan diatas dapa disimpulkan bahwa perselisihan dalam jemaat akan selalau ada, tetapi kejujuran dan kemauan dalam menyelesaikan perselisihan tersebut niscaya akan memulihkan hubungan yang retak karena konflik. Perselisihan yang tertangani dengan baik bisa memicu kedewasaan dalam berjemaat dan berdampak kepada pertumbuhan gereja.

\section{Kejujuran dalam Kepemimpinan}

Seorang pemimpin yang memiliki Kepribadian yang baik, jujur, akuntabilitas, berhati-hati, profesional, dan mengikuti aturan dan kurang mencari perhatian merupakan menerima peringkat integritas dan akuntabilitas yang tertinggi dalam sebuah kepemimpinan (Nei et al.,2018,p.17). Dalam melaksanakan kepemimpinannya, 
pemimpin dalam gereja tentunya mempunyai tanggung jawab yang sangat besar. Pemimpin Gereja harus meneladani cara pemimpin dalam Alkitab. Salah satu contoh yang bisa dilihat adalah dalam Mazmur 23. Dalam bagian ini selain belajar tentang sifat Allah juga bisa dilihat cara kepemimpinan-Nya. Pemazmur maupun penulis Injil menggunakan istilah "gembala" untuk menggambarkan kepemimpinan. Dalam Injil Kepemimpinan yang ditampilkan Yesus Kristus memberikan tiga gambaran kepemimpinan transformasional yang menarik, yakni sebagai Pelayan, Gembala, dan Pengurus (D'Souza, 2007, p. 23).

Dalam kaitannya dengan kejujuran dalam kepemimpinan, dewasa ini banya pemimpin gereja yang tidak lagi mempraktikkan kepemimpinan sebagai gembala. Sonny Eli Zaluchu yang dalam tulisannya tentang Intrik di Dalam Gereja mengatakan bahwa, "Kelemahan dalam kepemimpinan gereja yang sudah mulai rapuh biasanya ditandai dengan sejumlah kegiatan-kegiatan yang terkesan memaksakan kehendak, terjadi penggembalaan yang sudah tidak, mulut pemimpin yang tidak dapat di kontrol, masuknya intervensi orang- orang tertentu yang sangat kuat memengaruhi keputusan gembala. visi gembala yang begitu lemah, kehidupan doa yang kurang, sikap plin plan pemimpin, tidak mau mengakui kesalahan serta sikap tidak mau tahu, (Download Citation of Intrik Dalam Gereja, n.d.) Jujur dalam berpegang teguh pada firman Tuhan adalah identitas pemimpin gereja. Karakter kejujuran yang dimiliki seorang pemimpin gereja akan membuatnya lebih tegas dalam kepemimpinannya karena bertindak atas dasar Firman Tuhan yang kuat (F. Halverstadt, 2002, p. 52).

Masalah kepemimpinan yang tidak lagi mencerminkan identitasnya sebagai pemimpin gembala yang seyogianya harus menjalankan mandat Firman Tuhan tak pelak menimbulkan permasalahan di tengah jemaat. Sangat penting mengenai integritas seorang pemimpin. Pemimpin jemaat bukanlah kepemimpinan yang purapura.

\section{Kejujuran dalam Pemberian dan Pengelolaan Keuangan}

Memberi dalam konteks persembahan merupakan hubungan pribadi seseorang dengan Tuhan yang didasari oleh Firman Tuhan sendiri. Di dalam hukum Perjanjian Lama bangsa Israel diwajibkan untuk memberikan persepuluhan mereka sebagai pengakuan bahwa Allah sungguh memberkati mereka (Im 27:30-32). Persepuluhan tersebut dipergunakan untuk biaya-biaya ibadah dan dukungan untuk para imam. Dalam Perjanjian Baru Paulus mengatakan bahwa pelayanan pemberitaan injil perlu didukung. Mereka yang melayani dalam tempat kudus akan mendapat penghidupannya dari tempat kudus itu dan bahwa mereka yang melayani mezbah, mendapat bahagian mereka dari mezbah itu, demikian pula Tuhan telah menetapkan, bahwa mereka yang memberitakan Injil, harus hidup dari pemberitaan Injil itu.(1 Korintus 9: 13-14)(Damarwanti, 2015, p. 32). Atas dasar perintah Tuhan tersebut setiap anggota jemaat wajib hukumnya untuk jujur dalam hal memberi. 
Dalam kaitannya dengan pemberian jemaat terhadap pelayanan maka diperlukan juga pengelolaan keuangan secara jujur dan transparan. Transparansi pengelolaan keuangan dapat dilihat dalam hal pencatatan, pelaporan dan pertanggung jawaban, kebanyakan gereja sudah melakukan hal itu namun masih ada sebagian gereja belum memperhatikan masalah pengelolaan keuangan, dan terkesan tertutup bagi umat. Pengelolaan keuangan yang buruk biasanya muncul dari pribadi yang tidak jujur. Janet Silvia mengatakan Kegagalan gereja dalam mengelolah jemaat dan gereja itu sendiri berawal dari pribadi yang tidak memikirkan secara serius tentang pemberian jemaat suatu gereja. Sebab itu, dalam rangka membangun kepercayaan harus didukung gereja itu sendiri yaitu dengan memberitakan ajaran Tuhan untuk menanamkan konsep bahwa gereja adalah milik bersama sehingga diperlukan akuntabilitas yang transparan bagi public (Silvia \& Ansar, 2011, p. 2).

Berdasarkan uraian diatas dapat disimpulkan bahwa nilai-nilai karakter kejujuran dalam pemberian adalah dengan kejujuran memberi persembahan yang merupakan perintah Allah. Adapun hasil persembahan dari jemaat harus dipertanggungjawabkan melalui mekanisme pelaporan yang transparan.

\section{Kejujuran dalam Berkhotbah}

Pelayanan khotbah dalam sebuah gereja biasanya menjadi tanggung jawab gembala sidang tetapi seringkali tugas tersebut juga dilakukan oleh prebiter yang lain. Ketika berkhotbah seorang penghotbah sedang mempertaruhkan integritasnya sebagai penyambung lidah Allah. Berkhotbah bukan hanya sebatas berbicara kepada audiens untuk memuaskan pendengaran mereka tetapi pertanggung jawabannya yang terbesar yaitu kepada Allah sendiri. Khotbah haruslah memperlakukan kekayaan tradisi Alkitab dengan serius, berfokus pada tugas teologis dan tidak menganggap aneh konteks gerejawi dan jemaat (Schnasa Jacobsen, 2009, p. 19).

Dalam berkhotbah tentunya ada etika yang perlu mendapat perhatian, baik dari segi persiapan khotbah tersebut maupun dalam penyampaiannya. Banyak penghotbah yang "gagal" dalam mempersiapkan khotbahnya sehingga berdampak fatal juga kepada pengkomunikasian khotbah tersebut. Penghotbah sering tidak jujur kemudian mengambil jalan pintas untuk menjiplak khotbah orang lain kemudian disampaikan. Gaylord Noice mengatakan Kegagalan mempertautkan iman dan kebenaran menyebabkan plagiarisme dalam berkhotbah. Bahkan hal itu lebih parah dari pada mencuri tanah milik orang lain. Plagirisme khotbah yang sering dilakukan akan membuat lumpuhnya kreativitas pendeta yang merupakan hal yang begitu penting dalam kaitannnya dengan profesionalitas seorang pendeta. Plagiarisme akan menciptakan ketidak cocokan antara pendeta yang dikenal melalui khotbahnya dengan yang terlihat sehari-hari. Ketidakjujuran pendeta dalam berkhotbah akan menghilangkan integritasnya dan dampaknya pada menurunnya pelayanannya secara pribadi (Noice, n.d., p. 216). Pendeta yang tidak mempersiapkan khotbah atau pengajarannya dengan jujur akan berakibat pada pengajaran yang diterima oleh setiap anggota jemaat tidak akan terarah dengan baik (Sudjono, 2011, p. 2). Sune 
Fahlgren mengatakan krisis berkhotbah adalah krisis para pengkhotbah. Dan itu terdiri dari kurangnya alat untuk mempersiapkan dan menyampaikan khotbah. Saat diterapkan ke eklesiologi ini berarti bahwa Gereja membutuhkan alat (keterampilan) dan pendidikan yang lebih baik (Pengetahuan) untuk para gembalanya untuk memenuhi misinya di dunia saat ini (Fahlgren, 2006, p. 195).

Dengan demikian sangat penting memiliki karakter kejujuran dalam berkhotbah. Jujur dalam mempersiapkan bahan khotbah dan jujur dalam menyampaikan apa yang telah disiapkan. Tindakan-tindakan tidak etis dengan plagiasi akan melemahkan integritas seorang penghotbah yang bisa berdampak kepada hilangnya antusias jemaat dalam menerima pengajaran yang disampaikan.

\section{KESIMPULAN}

Berdasarkan hasil kajian ini, penulis menemukan bahwa nilai-nilai karakter kejujuran yang perlu dalam kehidupan jemaat dan gereja pada masa kini antara lain setiap warga gereja harus berkomunikasi secara jujur, setiap warga jemaat perlu memiliki kemauan dan kejujuran dalam penyelesaian suatu masalah, bagi pemimpin gereja perlu memiliki integritas yang tinggi dalam kepemimpinannya, mempraktikkan kejujuran dalam memberi persembahan dan transparansi pengelolaan persembahan itu sangat penting serta sebagai gembala jemaat perlu jujur dalam berkhotbah.

Kejujuran menurut Alkitab ialah melakukan sesuatu dengan sebuah motivasi yang benar dan tulus serta melakukan suatu perkara yang benar dan harus dilakukan. Dari dasar tersebut dan hasil penelitian ini disimpulkan bahwa kejujuran harus menjadi gaya hidup bergerja dan berjemaat sehingga setiap warga gereja memaknai kejujuran tersebut sebagai bentuk tanggung jawab kepada Allah dan gereja-Nya.

\section{KEPUSTAKAAN}

Amin, M. (2017). Peran Guru Dalam Menanamkan Nilai Kejujuran Pada Lembaga Pendidikan. Tadbir: Jurnal Studi Manajemen Pendidikan, 1(1), 105-124. https://doi.org/10.29240/jsmp.v1i1.222.

Damarwanti, S. (2015). Membaca Animo Pemuda dalam Memberikan Persembahan Persepuluhan. Sanctum Domine: Jurnal Teologl, 2(1), 31-42. https://doi.org/10.46495/sdjt.v2i1.20.

Dewi, K. G. S. S., Anantawikrama Tungga Atmadja, S. E., \& I Made Pradana Adiputra, S. E. (2015). Konsep Akuntabilitas Keuangan Dalam Organisasi Keagamaan (Studi Kasus Pada Gereja Kerasulan Baru Di Indonesia, Distrik Jawa Timur Dan Bali). JIMAT (Jurnal Ilmiah Mahasiswa Akuntansi) Undiksha, 3(1), Article 1. https://doi.org/10.23887/jimat.v3i1.4807.

Djadi, J. (2005). Peranan Pemuda Gereja Dalam Pembangunan Bangsa. Jurnal Jaffray, 3(1), 41-46. https://doi.org/10.25278/jj71.v3i1.142.

D'Souza, A. (2007). Proactive Visionary Leadership. Jakarta: Trisewu. 
F. Halverstadt, H. (2002). Mengelola Konflik Gereja. Jakarta: BPK Gunung Mulia.

Fahlgren, S. (2006). Preaching and preachership as fundamental expressions of being church. International Journal for the Study of the Christian Church, 6(2), 180 199. https://doi.org/10.1080/14742250600694124.

Inten, D. N. (2017). Penanaman kejujuran Pada Anak Dalam Keluarga. FamilyEdu: Jurnal Pendidikan Kesejahteraan Keluarga, 3(1), Article 1. https://ejournal.upi.edu/index.php/familyedu/article/view/5907.

Mansyur, U. (2018). Pemanfaatan Nilai Kejujuran dalam Cerpen Sebagai Bahan Ajar Berbasis Pendidikan Karakter. https://doi.org/10.17605/OSF.IO/Z4T3Y.

Mardikarini, S., \& Suwarjo, S. (2016). Analisis Muatan Nilai-Nilai Karakter Pada Buku Teks Kurikulum 2013 Pegangan Guru Dan Pegangan Siswa. Jurnal Pendidikan Karakter, 6(2), Article 2. https://doi.org/10.21831/jpk.v6i2.12057.

Murdiono, M. (2016). Pendidikan Anti Korupsi Terintegrasi dalam Pembelajaran PKn untuk Menanamkan Karakter Kejujuran di SMP. SOCIA: Jurnal Ilmu-Ilmu Sosial, 13(1), Article 1. https://doi.org/10.21831/socia.v13i1.9910.

Nei, K. S., Foster, J. L., Ness, A. M., \& Nei, D. S. (2018). Rule breakers and attention seekers: Personality predictors of integrity and accountability in leaders. International Journal of Selection and Assessment, 26(1), 17-26. https://doi.org/10.1111/ijsa.12201.

Noice, G. (2011). Tanggung Jawab Etis Pelayanan Jemaat. Jakarta: BPK Gunung Mulia. Nuhamara, D. (2018). Pengutamaan Dimensi Karakter Dalam Pendidikan Agama Kristen. Jurnal Jaffray, 16(1), 93-114. https://doi.org/10.25278/jj71.v16i1.278.

Putri, K. D., \& Dewantara, A. (2018). Mulai Punahnya Nilai Kejujuran Dikaji Dengan Buku Diskursus Pancasila Dewasa Ini. https://doi.org/10.31227/osf.io/6m38z.

Rumbi, F. P. (2019). Manajemen Konflik Dalam Gereja Mula-Mula: Tafsir Kisah Para Rasul 2:41-47. Evangelikal: Jurnal Teologi Injili dan Pembinaan Warga Jemaat 3 (1): 9-20. https://core.ac.uk/reader/231150420.

Schnasa Jacobsen, D. (2009). Schola Prophetarum: Prophetic Preaching Toward a Public, Prophetic Church. Homiletic:The Journal of The Academic of Homiletics. 34 (1), 12-21.

http://ejournals.library.vanderbilt.edu/ojs/index.php/homiletic/article/view/331 6.

Setiawan, D. E. (2019). Kelahiran Baru Di Dalam Kristus Sebagai Titik Awal Pendidikan Karakter Unggul. Evangelikal: Jurnal Teologi Injili dan Pembinaan Warga Jemaat, 3(2), 154-161. https://doi.org/10.46445/ejti.v3i2.135.

Setyono, F. (2013). Pengaruh Kualitas Komunikasi Interpersonal Pemimpin Kelompok Sel Terhadap Komitmen Organisasi Anggota Kelompok Sel Di Satelit Holy Gereja Mawar Sharon Surabaya. Jurnal E-Komunikasi, 1(2), Article 2. http://publication.petra.ac.id/index.php/ilmu-komunikasi/article/view/904.

Silvia, J., \& Ansar, M. (2011). Akuntabilitas Dalam Perspektif Gereja Protestan (Studi Fenomenologis Pada Gereja Protestan Indonesia Donggala Jemaat Manunggal Palu. http://pdeb.fe.ui.ac.id/?p=5663. 
Simangunsong, B. (2018). Gereja Melawan Korupsi: Konstruksi Nilai-Nilai Spiritualitas Anti Korupsi dalam Konteks Masyarakat Batak. Bia: Jurnal Teologi dan Pendidikan Kristen, '1(2), 2014-219.

http://www.jurnalbia.com/index.php/bia/article/view/52.

Sudjono, A. (2011). Inspirasi Roh Kudus Bagi Pendeta Dalam Mempersiapkan Khotbahnya. Jurnal Antusias, 1(3), 9-16. https://www.sttintheos.ac.id/ejournal/index.php/antusias/article/view/70.

Sugiyono. (2015). Metode Penelitian Kombinasi. Bandung: Alfabeta.

Sukmawati, F. (2020). Akuntabilitas Gereja dalam perspektif Alkitabiah dan Stewardship theori (Studi kasus pada Gereja X di Jawa Timur) / Franchisca Sukmawati. Skripsi Mahasiswa UM. http://mulok.library.um.ac.id/index3.php/74243.html.

White, J. (2012). Kejujuran Moral Dan Hati Nurani. Jakarta: BPK Gunung Mulia. Wijaya, H., \& Helaluddin, H. (2018). Hakikat Pendidikan Karakter. https://repository.sttjaffray.ac.id/publications/269450/hakikat-pendidikankarakter.

Ying, L., Ma, F., Huang, H., Guo, X., Chen, C., \& Xu, F. (2015). Parental Monitoring, Parent-Adolescent Communication, and Adolescents' Trust in Their Parents in China. PLOS ONE, 10(8). https://doi.org/10.1371/journal.pone.0134730.

Zaluchu, S. E. (2018). Analisis Kisah Para Rasul 15 Tentang Konflik Paulus dan Barnabas serta Kaitannya dengan Perpecahan Gereja. Kurios (Jurnal Teologi dan Pendidikan Agama Kristen), 4(2), 107-117. https://doi.org/10.30995/kur.v4i2.83.

Zimmermann, J. (2009). Change, Grief, and Conflict in Church Development in East Germany. International Journal of Practical Theology, 13(1), 46-61. https://doi.org/10.1515/IJPT.2009.4. 